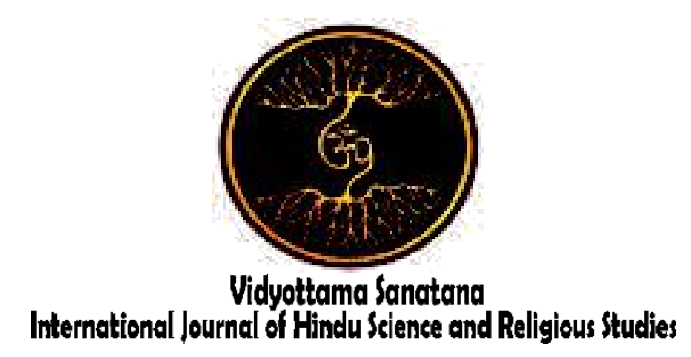

Vol. 3 No. 1 May 2019

\title{
PLACENTA CEREMONY FOR SOCIAL CULTURE AND HOPE HUMAN HINDU BALI
}

\author{
By: \\ Putu Agus Windu Yasa Bukian, Putu Dian Prima Kusuma Dewi \\ STIKES Buleleng \\ E-mail : pyasabukian2019@gmail.com
}

\begin{tabular}{|l|l|l} 
Received: March 11, 2019 & Accepted: May 26, 2019 & Published: May 31, 2019
\end{tabular}

\begin{abstract}
The birth process for Hindus is a sacred process and full of beauty. Special Hindu humans in Bali have gone through a very diverse ritual process since the womb. This research is a type of qualitative research that involves the socio-cultural values and expectations of Hindu Balinese people from the ceremony to mend the placenta. Information was collected from religious leaders, community leaders and Balinese Hindu couples who have babies. Descriptive analysis and content used to analyze the results of the data obtained. The results show the process of ceremony of placenta a hereditary process of inheritance carried out by Hindu communities in Bali. There is no significant change from this process in a sociocultural way because it considers the things that are commonly done by the philosophical media used to change some modifications. The hope and purpose of mending the placenta is still done through a short prayer. Many Balinese Hindu couples don't know about the special mantram that is said during the process of humming. It is recommended that the process of mending the placenta be carried out in accordance with the ceremony in accordance with Hindu literature through the guidance and guidance of traditional stakeholders and Hindu religious leaders, without changing food and support.
\end{abstract}

Keywords: Cultural Value, Hope, Mendem Ari-Ari, Qualitative

\section{Introduction}

The birth process for Hindus is a sacred process and full of beauty. Hindu humans, especially in Bali, have gone through a very diverse ritual process since the womb. Hindus in Bali recognize the human process from the womb to death. Birth as a form of sustainability for future generations. Babies 
who are born into the world are not alone. Based on Hindu beliefs, there are four brothers who follow which are called Chess Sanak. Because of that too, there is a special ritual procession, one of which is planting Ari-ari the baby. Ari-ari is part of the life of the baby who is the personification of the Chess Sang Sanak, namely the Anta Preta, Sang Kala, Sang Bhuta, and Sang Dengen (Sudharta, 2013).

The ceremony of placenta is symbolic of the union of land and space to invoke protection so that the blessed and healthy baby is always (Gautama, 2008; Sudharta, 2013). Bali has a culture of the ceremonial process of the placenta, which varies from planting in the yard and hanging system. Even though the ceremony to mend the placenta does not use complex offerings, the steps and procedures carried out are believed to be a form of parents' hopes for their children later. Process the placenta as a form of appreciating the beginning of the process of life.

Care for the placenta carried out with gratitude and happiness is able to provide a positive vibration for babies born (Çaya, 2015; Sharma, Teijlingen, Hundley, Angell, $\&$ Simkhada, 2016). Ceremony of placenta is one of the ceremonies that must be performed by Hindu families or Balinese people, because the placenta is an important part of the fetus's development in the womb. The process of mending the placenta as a symbol of the strength of local genius, Kanda Pat. Kanda Pat is a legacy of ancestors in Bali, in the Kanda Pat system it was stated that humans were born into the world assisted by four brothers, Ari-ari (placenta), shampoo, getih (blood) and yeh nyom (amniotic fluid). These four siblings keep babies in the womb and help with the birth of the baby (Arta, 2010; Arwati, 2006) (Agung, Mahadewi, Made, Sasmita, \& Wibawa, 2016).

The process of placenta for Hindus, especially in Bali, is one culture that needs to be maintained. The condition that occurs is that many Balinese couples do not know the procedure to mendem the correct placenta.
The husband and wife do not know the charm that must be said when mendem (I Wayan Sujana, Made Nila Yuwinda Sari, 2018). They carried out the process of ceremony of placenta without asking for instructions to sulinggih or even religious stakeholders so that many carried out this process without being based on proper literature. This study aims to delve deeper into the goals, meanings, and processes of mendem-ari carried out by Hindus today. Ceremony of placenta is not only fulfilling obligations as Hindus, but also as a form of hope and maintaining the stability of Hindu people in Bali which is known for its culture, art and uniqueness in its religion.

\section{Methods}

The study was conducted with a qualitative phenomenological method on couples, religious leaders, and traditional leaders in the community of Bungkulan Village, Sawan Sub-District, Buleleng. Data was collected by in-depth interviews with indigenous couples who had 0-1 month old babies, religious leaders and traditional leaders in Bungkulan Village. The analysis carried out is descriptive and content by gathering conditions, views that are held and concluding in the form of topics and conclusions. This in-depth interview is carried out until it reaches the saturation point or saturation point where all respondents have almost the same answer with the same question.

\section{Results And Discussion}

The phenomenological study of the ritual process of mending the placenta was carried out to find results that the ritual process mendem of the placenta was carried out as a form of cultural warsan hereditary from before. This is supported by the results of interviews conducted on married couples who have gone through the process stating that "no one provided specific information in writing about the procedure for removing the placenta, all of which are known orally from the stories of parents or previous generations". 
The ceremony to mend the placenta that was done using simple offerings, namely base tampih, canang sari, incense and all for chess relatives. The larger form of offerings is performed at the tugtug kambuhan ceremony, kepus pungsed and quarterly as a form of gratitude and respect for the chess of relatives.

\section{Perception of Religious Leaders and Customary Figures}

Ceremony of placenta becomes a sacred process and a form of gratitude to the Creator. The process of caring for the placenta is a sacred and hopeful ritual for the family (Beinempaka et al., 2014; I Wayan Sujana, Made Nila Yuwinda Sari, 2018). The perception of religious leaders in this case is Sulinggih, which describes the meaning and purpose of mendem-ari-ari as follows

"The aim is to make the placenta in Hinduism to entrust the motherland where this child will not be far away and be able to know themselves and their environment and be able to express themselves to their environment, family and who they are and who their family is to understand. the goal is spiritually but scientifically the placenta is dirty so it is obligatory that the placenta is planted in the yard of the house"

Ari-ari is part of the chess chess that is still attached to the baby at birth, which is respected through the humming process carried out in the yard of the house. Every place in Bali has a different city, but the socio-cultural meaning it has is the same, namely as a form of gratitude, respect and protection for the safety and health of babies (Gautama, 2008; Mangku Alit Pekandelan, 2010; Sudharta, 2013). The results of the interview also show that

"Every community that gives birth if they ask for an opinion from Sulinggih about how to support the placenta will be given, but now there are few people who have asked for guidance to Sulinggih because it is considered normal and has become a tradition but it is not based on literature"
The perception of the adat leaders, specifically Jero Mangku Desa, states that the meaning of the process of mendem-ariari is "Usually so that the process of unification of elements, which is in the arid, there are 5 elements there, there are elements of the five blind, can be integrated in, and united with motherland ". In essence the process of mending the placenta is part of prenatal care that is carried out with joy (Callister, 2010; Hussain, Ahmed, \& Bano, 2013).

Sulinggih as a religious leader in the community explained that "Every community that gives birth if they ask for an opinion from Sulinggih about how to mend the placebo will be given but now there are few people who ask for guidance to Sulinggih because it is considered normal and has become a tradition it is not based on literature ". The results of this study illustrate that the process of mending the placenta is a tradition in a series of processes of Hindu worship in Bali, but with a variety of busy activities so that many parts of the media and ritual processes are made more practical that are not in accordance with literature.

\section{Perception of Hindu Couples}

Husbands are the main family members who play a role in the process of mendem arid in the family. Description obtained from the results of in-depth interviews that "Doing the placenta is done so that children get protection from the land, and become the first media to put hope in children. Planting with the right hand with trust so that one day the child is not used to working with his left hand. There is no special mantle, just just mentioning the name of the most depressed child, putu, komang, ketut which aims to keep the child from dumb later."

Rituals in Hinduism have never been separated from upakara media and mantram as symbolic. Today's era is a lot of things that are made practical and easier so that this mindset makes many couples who do not prepare themselves ritually when the process is mendem-ari. It is evident from many 
couples not knowing the mantram, preparation and media included during the process of ceremony of placenta (I Wayan Sujana, Made Nila Yuwinda Sari, 2018; Mangku Alit Pekandelan, 2010).

\section{Socio-cultural Value}

Bali is an island with a million cultural heritage which is a local genius that needs to be preserved and maintained. The Balinese Hindu man has a characteristic upakara which has been carried out since the womb until he dies. The Balinese Hindu man did not ever escape from his yad from his god yad to his butha yad. One series of upakara since the baby is born is the process of mendemari the placenta. So far what has been taken into account in Balinese society is the three-month ceremony, tugtug kambuhan and otonan, even though since the birth of the baby the river has been protected by Chess Sanak, one of the placenta. The process of mending the placenta is a process that is considered a hereditary inheritance carried out following the tradition that has been carried out. Though a lot of media and upakara are prepared with their functions and meanings.

According to Lontar Anggastyaprana, that the process of caring for the placenta (cleansing and planting), aims as a form of exclamation and begs Sang Hyang Mother Earth and Hyang Akasa to receive, provide protection and long life and safety of life for the baby. Symbolically the coconut fruit that is tattooed with the writing Omkara at the top as an expression of Hyang pertiwi. The lights and rays that always light up above the placenta symbolize the holy rays and souls of Hyang Akasa and Hyan pertiwi. The included thorns are symbolized as weapons for the chess of relatives and babies. Betel curves as a form of service live together physically and mentally between the chess relatives and babies (Arta, 2010; Arwati, 2006; Ayu et al., 2017).

\section{Hope and Objectives Ceremony of Placenta}

Balinese Hindus have different taksu and aura of their own because they are believed to have many hopes, prayers and yad that have been done even since the baby is in the womb. Hope for the baby will be explicitly reflected in the beginning of the process of mendem-ari, with the presence of inscriptions bearing letters, media duri and mapu penyinar included. The hope is that the chess that is born with the baby always provides protection.

\section{Conclusion}

The process of ceremony of placenta is a series of ceremonial forms of respect, gratitude for baby's birth. The socio-cultural and philosophical values of the process of mending the placenta are still very strong in the community because it is not only a form of yad but also a form of tradition and inheritance from generation to generation. Hope and best prayers begin with the process of mendem-ari-ari with the writing of letters, prayers and hopes that are included in the media before being planted. Besides that, it shows hope at the beginning so that Balinese Hindu people can maintain harmony with the Chess Chancellor. lhiran baby and get protection from the Creator.

\section{References}

Agung, I. G., Mahadewi, S., Made, G., Sasmita, A., \& Wibawa, K. S. (2016). Aplikasi Animasi 3 Dimensi Ceremony of placentaBerbasis Android, 4(1), 114-122.

Arta, K. S. (2010). Prosesi Upacara Ari-Ari Dengan Sistem Gantung (Studi Kasus pada Masyarakat Desa Adat Bayung Gede Kabupaten Bangli), (2).

Arwati, N. M. S. (2006). Upacara Manusa Yadnya. Denpasar.

Ayu, I., Arniati, K., Veda, R., Veda, S., Veda, Y., Sedangkan, V., \& Smrti, V. (2017). Aspek fungsional upacara.

Beinempaka, F., Mnsc, B., Tibanyendera, B., Med, B. A., Atwine, F., \& Mnsc, B. (2014). The practice of traditional 
rituals and customs in newborns by mothers in selected villages in, 19(2), 2014.

Callister, L. C. (2010). Spirituality in Childbearing Women, 19(2), 16-24. https://doi.org/10.1624/105812410X49 5514

Çaya, S. (2015). Beliefs Related to ChildBirth in a Western Anatolian Town : A Review Article, 11(8), 36-43. https://doi.org/10.3968/7440

Gautama, W. B. (2008). Tutur Rare Angon. Denpasar: Paramita.

Hussain, R., Ahmed, Z., \& Bano, P. (2013). Ethnographical study of postpartum practices and rituals in altit hunza, 132(12), 464-469.

I Wayan Sujana, Made Nila Yuwinda Sari, P. D. P. K. D. (2018). Aplikasi Proses
Mendem Ari-ari Sebagai Kearifan Budaya Lokal Umat Hindu. Vidya Samhita, 19(1), 72-81.

Mangku Alit Pekandelan, I. W. Y. (2010). Kanda Empat Rare Mewujudkan Keluarga Bahagia Selamat SekalaNiskala. Surabaya: Paramita.

Sharma, S., Teijlingen, E. Van, Hundley, V., Angell, C., \& Simkhada, P. (2016). Dirty and 40 days in the wilderness: Eliciting childbirth and postnatal cultural practices and beliefs in Nepal. BMC Pregnancy and Childbirth, 1-12. https://doi.org/10.1186/s12884-0160938-4

Sudharta, T. R. (2013). Manusia Hindu Dari Kandungan Sampai Perkawinan. Denpasar: Pustaka Bali Post. 